\title{
The role of extracellular slime in opsonophagocytosis of Staphylococcus epidermidis
}

\author{
K. G. KRISTINSSON*, J. G. M. HASTINGSt and R. C. SPENCER
}

\section{Department of Bacteriology, Royal Hallamshire Hospital, Sheffield S10 2JF and TDepartment of Medical Microbiology, University of Sheffield Medical School, Beech Hill Road, Sheffield S10 2RX}

\begin{abstract}
Summary. Infections caused by coagulase-negative staphylococci (CNS) are a major problem in immunocompromised patients. It has been claimed that extracellular slime production by CNS predicts pathogenicity and inhibits host defences. Luminolenhanced neutrophil chemiluminescence (CL) and bacterial killing assays were used to assess the effect of slime production on opsonophagocytosis and killing by polymorphonuclear leucocytes in vitro. There was wide variation in CL induction amongst the 43 strains of Staphylococcus epidermidis examined. The presence of slime had no influence either on the requirement or on the efficiency of opsonisation. Slimeproducing and non-slime-producing strains showed a stepwise increase in induced CL up to a serum concentration of $10 \%$, and were dependent on complement for efficient phagocytosis. The bacterial killing assays confirmed the CL results. Our data suggest that extracellular staphylococcal slime has no specific anti-opsonic property in vitro. Opsonophagocytosis may still be hampered in vivo by the physical presence of slime.
\end{abstract}

\section{Introduction}

Infections caused by coagulase-negative staphylococci (CNS) have increased in recent years and are amongst the commonest nosocomial infections (Center for Disease Control, 1986); most are associated with implanted foreign bodies. The increase is probably the result of the increasing number of immunocompromised patients with indwelling prosthetic biomaterials rather than any change in virulence of the organisms. CNS are now the commonest cause of foreign body infections (Fitzgerald et al., 1977; Karchmer et al., 1983; Press et al., 1984; Price, 1984).

Because CNS comprise a major part of the normal skin flora of man, assessing the significance of their isolation from infected patients may be difficult. Attempts to find a laboratory marker that correlates with pathogenic potential have been largely unsuccessful. Recently, extracellular slime production by CNS has been claimed to predict pathogenicity (Ishak et al., 1985; Davenport et al., 1986). This slime enhances adherence to plastic materials (Christensen et al., 1982; Peters et al., 1982), inhibits the cellular immune response (Gray

Received 18 Sept. 1987 ; accepted 11 May 1988

*Present address: Department of Bacteriology, University of Iceland, v/Baronstig, PO Box 1465, 121 Reykjavik, Iceland.

†Correspondence should be sent to Dr J. G. M. Hastings. et al., 1984), interferes with granulocyte function (Johnson et al., 1986) and is associated with recurrences of peritonitis in patients undergoing continuous ambulatory peritoneal dialysis (CAPD) (Kristinsson et al., 1986). It has also been postulated that slime may protect the bacteria against opsonophagocytosis (Peters and Pulverer, 1984).

To assess the effect of slime production on opsonisation, phagocytosis and killing by human polymorphonuclear leucocytes (PMNL), we have studied the effects of slime production by strains of Staphylococcus epidermidis on opsonophagocytosis as assessed in vitro by neutrophil chemiluminescence (CL) and on killing, as determined by standard bacterial killing assays.

\section{Materials and methods}

\section{Bacterial strains}

A collection of 118 isolates of CNS was available for study. All were from peritoneal effluents of patients who developed peritonitis whilst undergoing CAPD and have been described in detail by Kristinsson et al. (1986). The strains were identified according to the classification scheme of Kloos and Schleifer (1975) by the API Staph system (API Laboratory Products Ltd, Basingstoke). For the chemiluminescence experiments, 20 slime-producing and 23 non-slime-producing strains of $S$. epidermidis were selected at random for study. Each strain was tested at 
least twice and results were expressed as the mean. Bacteria were grown for $24 \mathrm{~h}$ at $37^{\circ} \mathrm{C}$ (i.e., to the stationary phase of growth), in either Tryptone Soya Broth (TSB; Oxoid), which facilitates slime production by CNS (Ludwicka et al., 1984), or Nutrient Broth (NB; Oxoid Nutrient Broth No. 2), which does not. The bacteria were harvested by centrifugation, washed once with saline, and then dispersed and resuspended by vortex mixing in Hanks's Buffered Salts Solution (HBSS) to a final concentration of $(0 \cdot 5-1) \times 10^{9} \mathrm{cfu} / \mathrm{ml}$.

\section{Slime production}

Slime production was detected by the method of Christensen et al. (1982). Briefly, five or six colonies from a purity plate of the test strain were inoculated into $10 \mathrm{ml}$ of TSB in glass test tubes ( $1 \mathrm{~cm}$ internal diameter). The cultures were incubated for $24 \mathrm{~h}$ at $35^{\circ} \mathrm{C}$, and then poured out of the test tubes. The inside of each tube was stained with an aqueous solution of safranin (0.25\%). Adherent growth was considered to be present if a stained film lined the inner surface of the tube and this was taken as an indication of slime production. The mere presence of a ring at the liquid-air interface was not considered to be a positive result.

\section{Serum}

Serum was collected from four healthy human donors, pooled and stored at $-70^{\circ} \mathrm{C}$ until used. Complement was inactivated by heating the serum to $56^{\circ} \mathrm{C}$ and holding for $30 \mathrm{~min}$. For serum antibody absorption, bacteria were harvested in $1 \mathrm{~L}$ of TSB and pelleted by centrifugation. Five volumes of serum were then mixed with one volume of bacteria and incubated for $1 \mathrm{~h}$ at $4^{\circ} \mathrm{C}$. Complement activation was blocked by $10 \mathrm{~mm}$ ethylenediamine tetraacetate (EDTA; Sigma).

\section{PMNL preparation}

Two volumes of fresh whole blood from healthy human donors, anticoagulated with preservative-free heparin $10 \mathrm{U} / \mathrm{ml}$, were mixed with one volume of dextran $6 \%$ in sodium chloride $0.9 \%$ and the red cells were allowed to sediment for $1 \mathrm{~h}$. The leucocyte-rich supernate was drawn off, centrifuged for $10 \mathrm{~min}$ at $2000 \mathrm{rpm}(350 \mathrm{~g})$, and the residual red cells lysed by osmotic shock. After washing twice with HBSS, the leucocytes were resuspended in HBSS supplemented with heat-inactivated fetal calf serum $1 \%$ to a PMNL concentration of $10^{6} / \mathrm{ml}$.

\section{Opsonisation}

Bacteria $\left(10^{9} \mathrm{cfu} / \mathrm{ml}\right)$ were mixed with whole serum, heated serum or absorbed serum, at a final concentration of $10 \%$, for $20 \mathrm{~min}$ at $37^{\circ} \mathrm{C}$. In some experiments, serum at different concentrations was used. After centrifugation the pellet was washed twice and resuspended to the original cell concentration in HBSS. Zymosan $10 \mathrm{mg} / \mathrm{ml}$ was opsonised by the same procedure with $10 \%$ serum.

\section{Chemiluminescence assay}

The method has previously been described by Easmon et al. (1980). PMNL chemiluminescence (CL) was enhanced with luminol (5-amino-2, 3-dihydro-1, 4 phtalazinedione; Sigma) and measured at $37^{\circ} \mathrm{C}$ in a photometer (Luminometer 1250, LKB Wallac). The reaction mixture consisted of PMNL suspension $\left(10^{6}\right.$ cells $\left./ \mathrm{ml}\right) 0.5 \mathrm{ml}$, luminol $\left(2 \times 10^{-6} \mathrm{M}\right) 0.9 \mathrm{ml}$ and bacterial suspension $0.2 \mathrm{ml}$. The light generated was recorded in $\mathrm{mV}$ and the readings were taken every $5 \mathrm{~min}$ for $45 \mathrm{~min}$. To minimise day-to-day variation in the readings, opsonised zymosan (Sigma) was used as a control and the data are presented as the $C L$ reading $(\mathrm{mV})$ relative to that induced by opsonised zymosan.

\section{Killing assays}

A 400- $\mu$ l volume of PMNL suspension $\left(10^{6}\right.$ cells $\left./ \mathrm{ml}\right)$, prepared as described above, was mixed with $200 \mu \mathrm{l}$ of bacteria $\left(10^{9} \mathrm{cfu} / \mathrm{ml}\right)$ and $200 \mu \mathrm{l}$ of serum. A $100-\mu \mathrm{l}$ sample was immediately transferred to $10 \mathrm{ml}$ of ice-cold sterile water, and a viable count performed $\left(t_{0}\right)$ by a spread-plate technique $(0.1 \mathrm{ml}$ of serial tenfold dilutions was spread on blood agar). The remaining mixture was incubated at $37^{\circ} \mathrm{C}$ for $45 \mathrm{~min}$ on a roller tray and a second $100-\mu$ sample was then transferred to $10 \mathrm{ml}$ of ice-cold sterile water and a second viable count $\left(t_{45}\right)$ was made. PMNL-free and serum-free controls were included for each strain and the relative reduction of viable bacteria in the mixtures containing PMNL was expressed as percentage killing.

\section{Statistics}

The mean $\mathrm{CL}$ responses were compared by the unpaired $t$-test.

\section{Results}

\section{Effect of slime production on CL response}

Strain-to-strain variation in CL induction was observed, especially with opsonised bacteria (fig. 1). Mean CL induction by unopsonised slimeproducing strains was significantly greater than mean CL generated by unopsonised non-slimeproducers (68 vs 39, $\mathrm{t}=4.3, \mathrm{df}=41, \mathrm{p}<0.005$; $\mathrm{SD}=25 \cdot 1$ vs $19 \cdot 4$ ). The difference between the mean CL values of the opsonised strains was not statistically significant ( 183 vs $190, t=0 \cdot 2, d f=41$, $\mathrm{p}>0 \cdot 1 ; \mathrm{SD}=106$ vs 104$)$. When the $\mathrm{CL}$ values of opsonised slime-producers grown in NB were compared with the CL values of the same strains 
grown in TSB there was no significant difference (results not shown).

\section{Opsonic requirements}

CL induction by opsonised CNS increased stepwise up to a serum concentration of $10 \%$ (fig. 2). Both slime-producing and non-producing CNS induced only low CL values when complementdepleted (i.e., heated) serum was used as an opsonin (fig. 3). Absorption of serum with either slimeproducing or non slime-producing CNS strains also reduced opsonisation but to a much smaller extent (fig. 3).

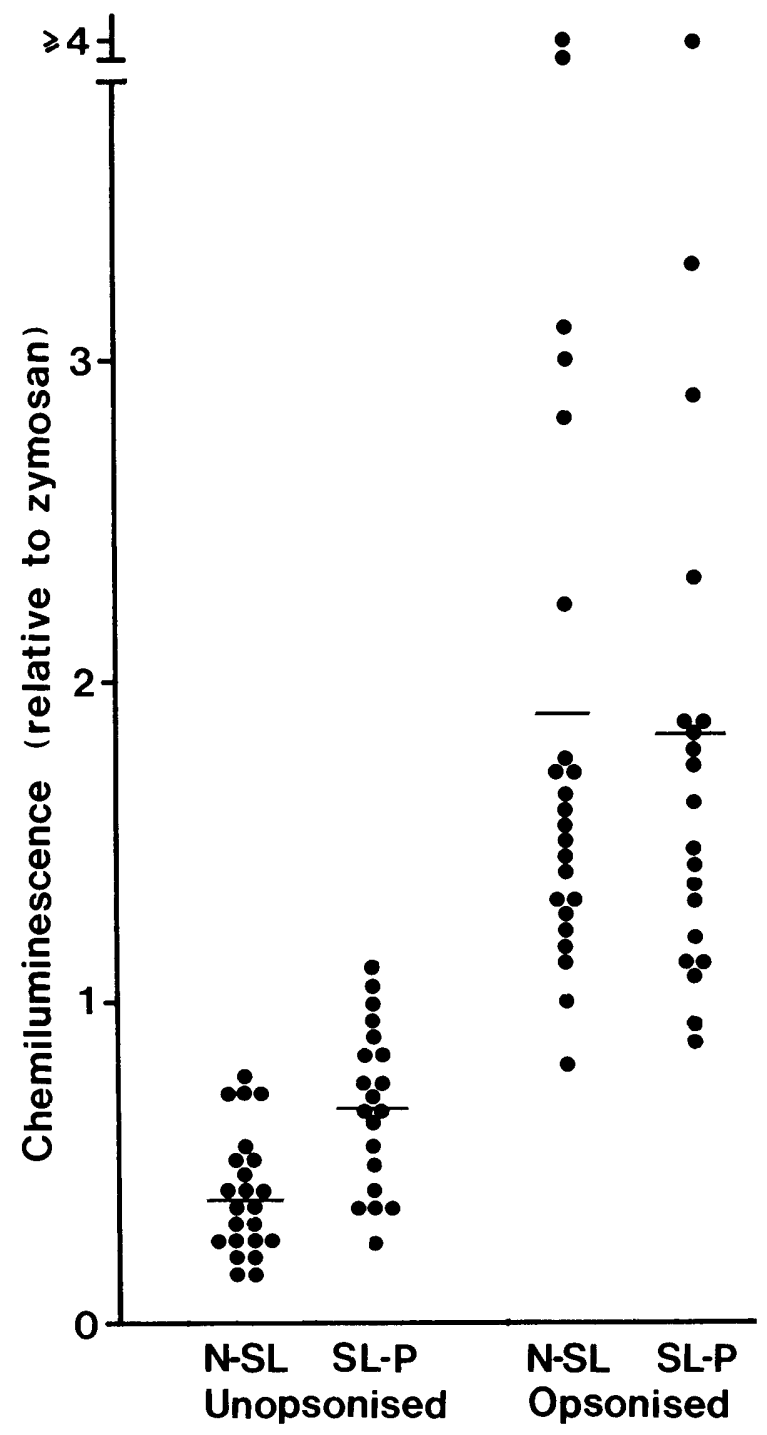

Fig. 1. CL induced by non-slime-producing (N-SL) and slimeproducing (SL-P) $S$. epidermidis strains opsonised with whole serum $20 \%$. Bars represent mean values.

\section{Killing assays}

Killing assays were performed on nine slimeproducing and eight non-slime-producing $S$. epidermidis strains (fig. 4). With all strains there was a reduction in viable counts after $45 \mathrm{~min}$. There was considerable variation between isolates but this did not appear to be related to slime production - mean reduction $60.0 \%$ (slime producers) vs $60.5 \%$ (nonproducers).

Four slime-producing $S$. epidermidis strains grown in TSB and NB were compared in PMNL killing assays (fig. 5). Although these strains showed increased slime-production in TSB, results in the killing assay were not significantly different.

\section{Discussion}

Opsonisation is considered to be a pre-requisite for efficient phagocytosis and intracellular killing of bacteria. Resistance to opsonisation is a virulence factor for some organisms (Quie et al., 1981). All 43 CNS strains in our study depended on complement for efficient opsonisation. Clark and Easmon (1986) investigated $18 \mathrm{~S}$. epidermidis isolates and found a similar pattern. However, other authors have reported strains of $S$. epidermidis that are well opsonised by complement-deficient serum (Fleer $e t$ al., 1985). Direct comparisons are difficult because the latter workers used a phagocytosis assay based on radio-labelled organisms, whereas we relied on luminol-dependent CL and bacterial killing assays. Other variations in experimental conditions may also account for different findings; studies of the kinetics of opsonisation have shown that serum concentration and incubation time are important variables when studying opsonic requirements (Tofte et al., 1980; Williams et al., 1980). The CNSspecific antibody concentration in the serum pools may also have been different. Despite these reservations, variations in susceptibility to serum opsonisation may be a feature of $S$. epidermidis. Indeed, we found considerable variation between CNS strains in susceptibility to opsonisation by the same pool of serum (fig. 1). These observations emphasise the need to assess a range of strains when studying pathogenic mechanisms.

The presence of extracellular slime had no influence either on the opsonic requirement or on the efficiency of opsonisation at any of the serum concentrations employed. Bacterial killing assays with selected strains again failed to demonstrate a role for slime in mediating resistance of CNS to phagocytic killing. The bacterial glycocalyx, whether loosely bound (slime) or firmly bound 


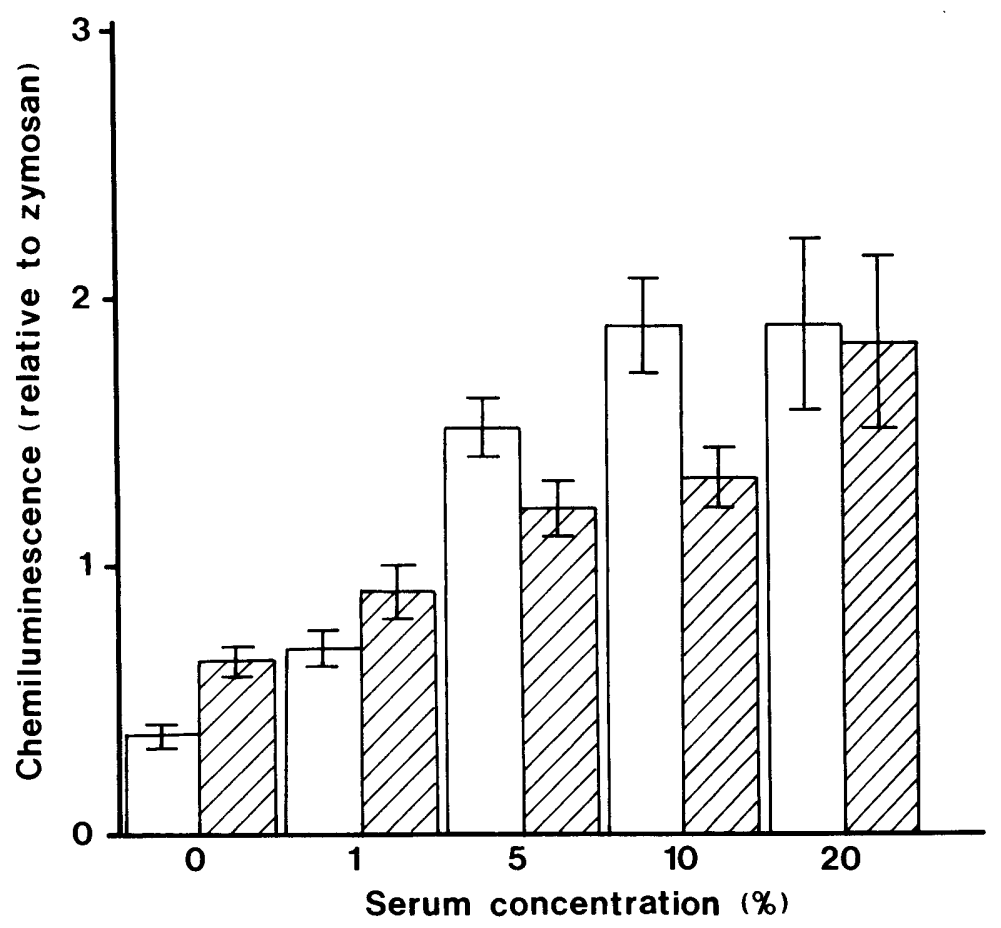

Fig. 2. $C L$ induced by $S$. epidermidis strains opsonised with different concentrations of whole serum. Histograms represent mean values \pm SEM (bars); $\square$ Non-slime producers; $\square$ slime-producers.

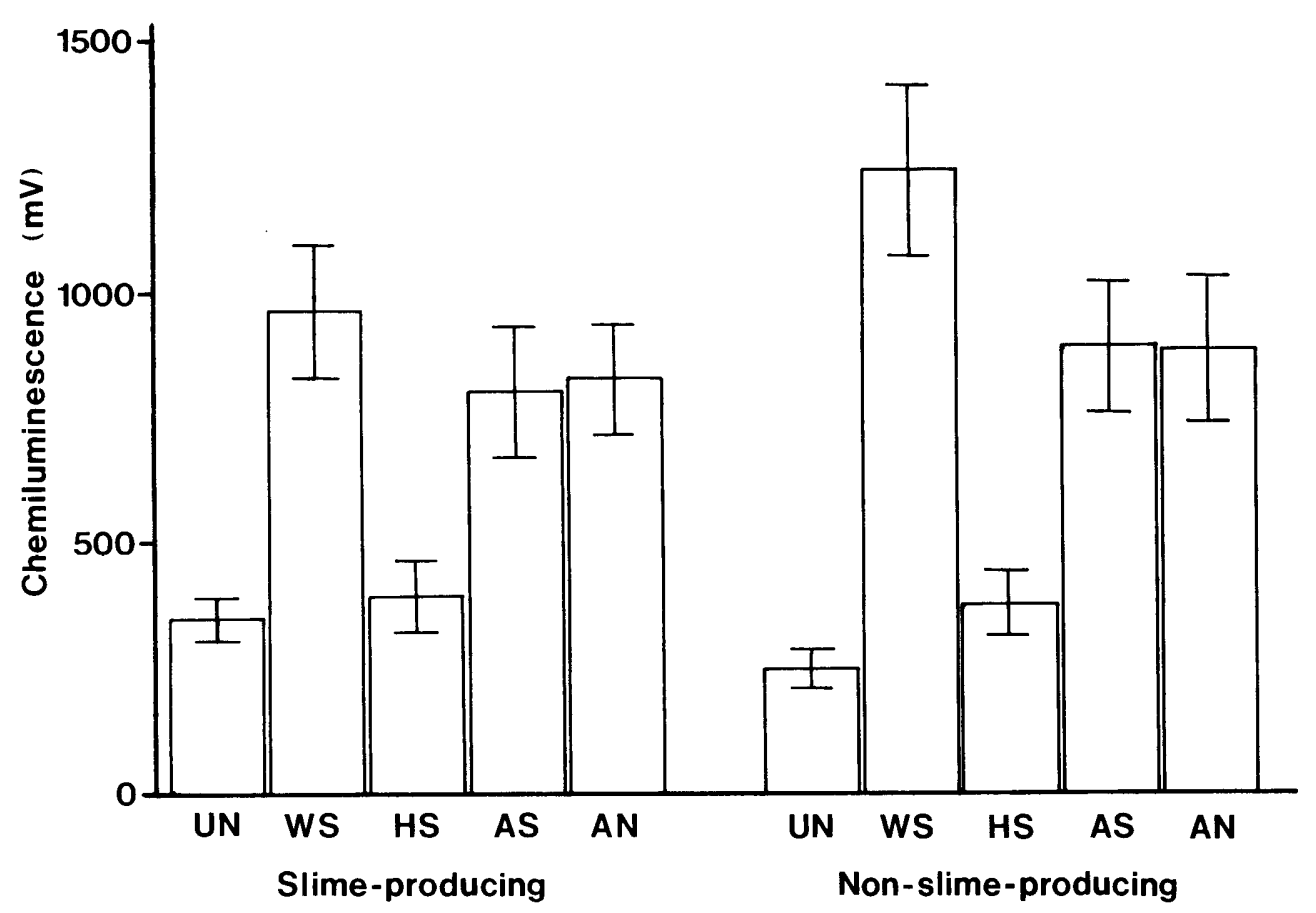

Fig. 3. $\mathrm{CL}(\mathrm{mV})$ induced by $20 \mathrm{~S}$. epidermidis strains. Histograms represent mean values $\pm \mathrm{SEM}$ (bars); UN = unopsonised; $\mathrm{WS}=$ whole serum $; \mathrm{HS}=$ heated serum; $\mathrm{AS}=$ serum absorbed by a slime-producing strain $; \mathrm{AN}=$ serum absorbed by a non-slimeproducing strain. 


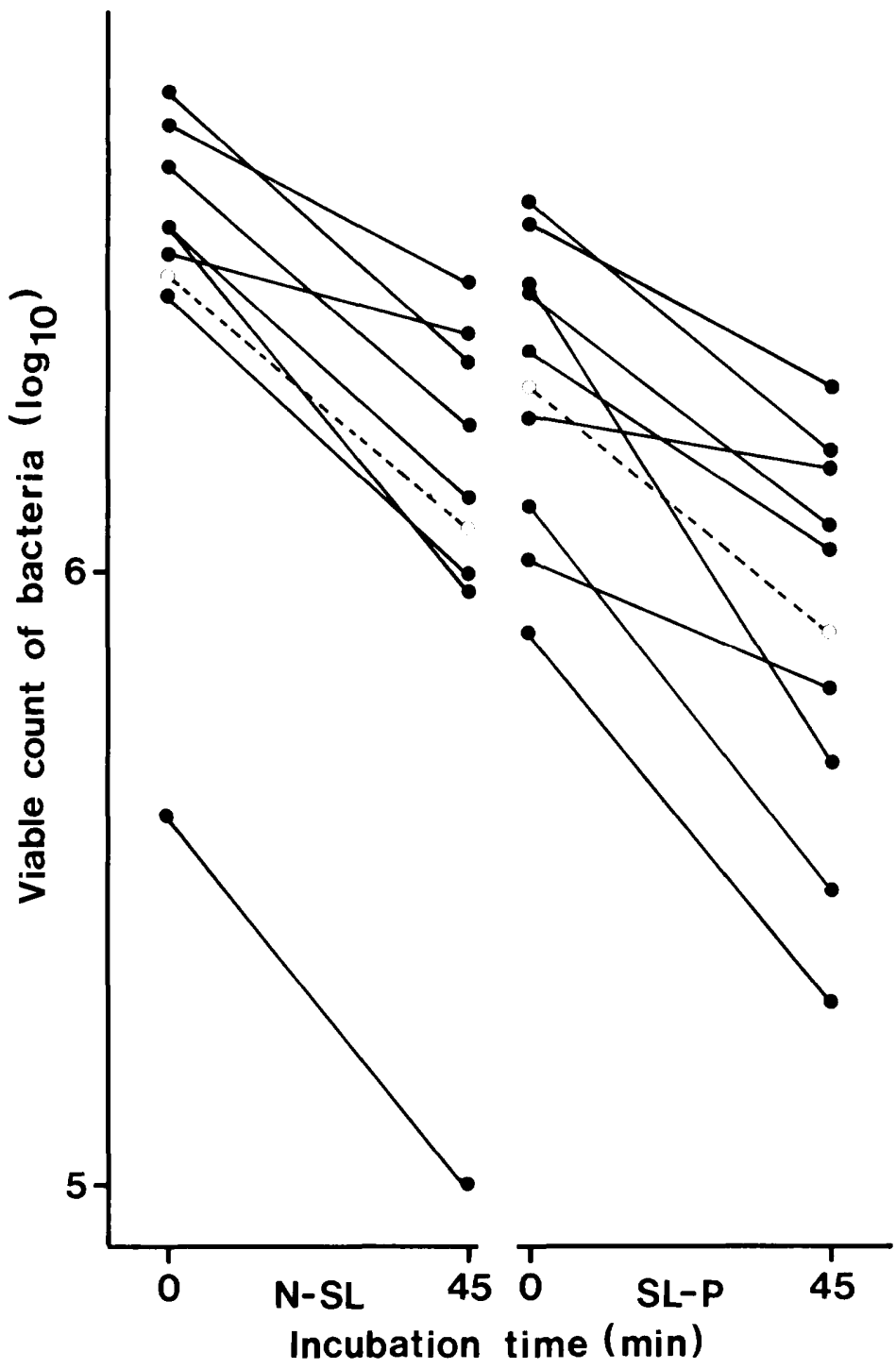

Fig. 4. Phagocytic killing of non-slime-producing (N-SL) and slime-producing (SL-P) S. epidermis strains. The dotted line represents the mean reduction in viable counts.

(capsule), may inhibit opsonisation by virtue of its ability to bind and neutralise immunoactive compounds. Our data suggest that the extracellular, loosely bound mucopolysaccharide that surrounds some CNS isolates has no such specific anti-opsonic property.

Bacterial killing assays and, to a lesser extent, CL studies, rely on the premise that one colony is equivalent to one organism, therefore our assay procedure included vortex mixing of bacterial suspensions to disperse clumps. It may be argued that, because of its water solubility, slime is washed off during this procedure. However, we believe that enough slime remains on the surface to maintain the physicochemical properties of the cells. This premise is supported by the fact that, after vortex mixing, slime producers demonstrated the same stickiness or readiness to clump as before treatment. Furthermore, previous scanning electronmicroscopy studies had demonstrated some surface slime even after vortex mixing (K. G. Kristinsson, unpublished observation).

$\mathrm{CL}$ is a by-product of the PMNL respiratory burst and is a function of membrane stimulation. Light production is related to the efficiency of PMNL-bacterial surface contact. The increased 


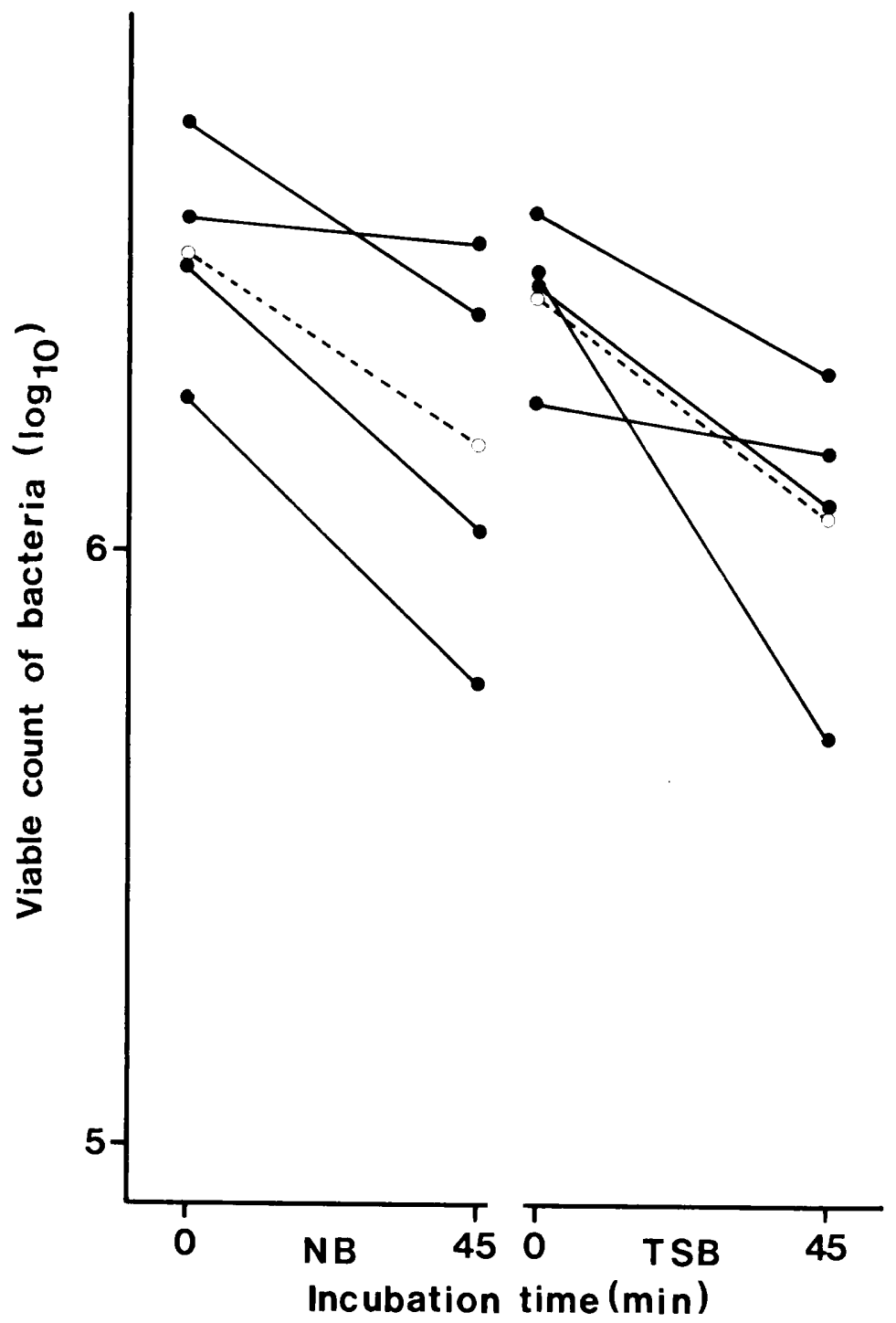

Fig. 5. Phagocytic killing of slime-producing S. epidermidis strains grown in TSB or NB. The dotted line represents the mean reduction in viable counts.

PMNL CL induced by non-opsonised slime-producing strains compared with that induced by nonslime-producing isolates may be related to changes in charge or hydrophobicity of the bacterial cell surface caused by the presence of an extracellular slime layer. These observations with PMNL CL were not reflected in the killing assays; neither slime-producing nor non-slime-producing CNS strains showed any reduction in viable counts in the serum-free experiments.

Electronmicroscopy has shown that slime production on plastic surfaces allows microcolonies of CNS to flourish beneath a protective coating of slime (Peters et al., 1981, 1982). Under these circumstances, effective opsonisation and phagocytosis may be significantly hampered by the physical presence of slime. Support for this suggestion has been given by a recent report in which reduced phagocytosis of slime-producing CNS was demonstrated by radio-labelled bacteria adherent to plastic wells (Johnson et al., 1986).

We thank Mr K.M. Oxley for technical assistance and we are grateful to the Division of Hospital Infections, PHLS, Colindale, for phage typing and biotyping the strains, and to Eli Lilly Co. for financial assistance. 


\section{REFERENCES}

Center for Disease Control 1986 Nosocomial infection surveillance 1984. CDC Surveillance Summaries, US Department of Health and Human Services 35 : no. 1SS.

Christensen G D, Simpson W A, Bisno A L, Beachey E H 1982 Adherence of slime-producing strains of Staphylococcus epidermidis to smooth surfaces. Infection and Immunity 37: 318-326.

Clark L A, Easmon C S F 1986 Opsonic requirements of Staphylococcus epidermidis. Journal of Medical Microbiology 22: 1-7.

Davenport D S, Massanari R M, Pfaller M A, Bale M J, Streed S A, Hierholzer W J 1986 Usefulness of a test for slime production as a marker for clinically significant infections with coagulase-negative staphylococci. Journal of Infectious Diseases 153: 332-339.

Easmon C S F, Cole P J, Williams A J, Hastings M 1980 The measurement of opsonic and phagocytic function by Luminol-dependent chemiluminescence. Immunology 41 : $67-74$.

Fitzgerald R H, Nolan D R, Ilstrup D M, Van Scoy R E, Washington J A, Coventry M B 1977 Deep wound sepsis following total hip arthroplasty. Journal of Bone and Joint Surgery 59A: 847-855.

Fleer A et al. 1985 Opsonic defense to Staphylococcus epidermidis in the premature neonate. Journal of Infectious Diseases 152: 930-937.

Gray E D, Peters G, Verstegen M, Regelmann W E 1984 Effect of extracellular slime substance from Staphylococcus epidermidis on the human cellular immune response. Lancet 1 : 365-367.

Ishak M A, Groschel D H M, Mandell G L, Wenzel R P 1985 Association of slime with pathogenicity of coagulasenegative staphylococci causing nosocomial septicaemia. Journal of Clinical Microbiology 22: 1025-1029.

Johnson, G M, Lee D A, Regelmann W E, Gray E D, Peters G, Quie P G 1986 Interference with granulocyte function by Staphylococcus epidermidis slime. Infection and Immunity 54: 13-20.

Karchmer A W, Archer G L, Dismukes W E 1983 Staphylococcus epidermidis causing prosthetic valve endocarditis: micro- biologic and clinical observations as guides to therapy. Annals of Internal Medicine 98: 447-455.

Kloos W E, Schleifer K H 1975 Simplified scheme for routine identification of human Staphylococcus species. Journal of Clinical Microbiology 1 : 82-88.

Kristinsson K G, Spencer R C, Brown C B 1986 Clinical importance of production of slime by coagulase negative staphylococci in chronic ambulatory peritoneal dialysis. Journal of Clinical Pathology 39: 117-118.

Ludwicka A et al. 1984 Investigation on extracellular slime substance produced by Staphylococcus epidermidis. Zentralblatt für Bakteriologie, Mikrobiologie und Hygiene, Abteilung A 258: 256-267.

Peters G, Locci R, Pulverer G 1981 Microbial colonization of prosthetic devices, II. Scanning electron microscopy of naturally infected intravenous catheters. Zentralblatt für Bakteriologie, Mikrobiologie und Hygiene, I. Abteilung Originale B 173: 293-299.

Peters G, Locci R, Pulverer G 1982 Adherence and growth of coagulase-negative staphylococci on surfaces of intravenous catheters. Journal of Infectious Diseases 146: 479-482.

Peters G, Pulverer G 1984 Pathogenesis and management of Staphylococcus epidermidis "plastic" foreign body infections. Journal of Antimicrobial Chemotherapy 14 Suppl D: 67-71.

Press O W, Ramsey P G, Larson E B, Fefer A, Hickman R O 1984 Hickman catheter infections in patients with malignancies. Medicine 63: 189--200.

Price E H 1984 Staphylococcus epidermidis infections of cerebrospinal fluid shunts. Journal of Hospital Infection 5: 7-17.

Quie P G, Giebink G S, Peterson P K 1981 Bacterial mechanisms for inhibition of ingestion by phagocytic cells. In: O'Grady $\mathrm{F}$, Smith $\mathrm{H}$ (eds) Microbial perturbation of host defences. Academic Press, London, pp 121-135.

Tofte R W, Peterson P K, Kim Y, Quie P G 1980 Influence of serum concentration on opsonization by the classical and alternative complement pathways. Infection and Immunity 27: 693-696.

Williams A J, Hastings M J G, Easmon C S F, Cole P J 1980 Factors affecting the in vitro assessment of opsonization: a study of the kinetics of opsonization using the technique of phagocytic chemiluminescence. Immunology 41 : 903-911. 